\title{
Antibacterial, Antiurease, and Antioxidant Activities of Some Arylidene Barbiturates
}

\author{
Bahar Bilgin Sokmen • Serpil Ugras • \\ Hasan Yucel Sarikaya • Halil Ibrahim Ugras • \\ Refiye Yanardag
}

Received: 1 July 2013 / Accepted: 28 August 2013/

Published online: 11 September 2013

(C) The Author(s) 2013. This article is published with open access at Springerlink.com

\begin{abstract}
Some series of arylidene barbiturates and thiobarbiturates were evaluated for their antibacterial, antioxidant, and urease inhibition activities. The arylidene barbiturates and thiobarbiturates were tested for antimicrobial activity using the agar well diffusion technique against 13 bacteria. The synthesized compounds $(1 \mathrm{a}-\mathrm{g})$ were screened for antiurease and antioxidant activities. The results showed that the synthesized compounds (1a-g) had effective antiurease, antioxidant, and antibacterial activities.
\end{abstract}

Keywords Arylidene barbiturates $\cdot$ Antibacterial $\cdot$ Antioxidant $\cdot$ Urease inhibition activity

\section{Introduction}

Barbituric acids have attracted the attention of the pharmaceutical scientist for over 100 years due to their therapeutic value [1]. Barbituric acid and its derivatives have exhibited biological activities such as in antibacterial, hypotensive, and antisclerotics [2], sedative, hypnotic, antispasmodic, anticonvulsant, and local anesthetic drugs [3,4] as well as in anticancer [5], anti-inflammatory [6], and matrix metalloproteinase inhibitors [7].

B. B. Sokmen $(\bowtie) \cdot$ H. I. Ugras

Department of Chemistry, Faculty of Arts and Sciences, Giresun University, 28049 Giresun, Turkey e-mail: baharsokmen@yahoo.com

H. I. Ugras

e-mail: halilugras@gmail.com

S. Ugras

Department of Biology, Faculty of Arts and Sciences, Giresun University, 28049 Giresun, Turkey

e-mail: serpilkus@gmail.com

H. Y. Sarikaya

Science Lycee of Giresun, 28049 Giresun, Turkey

e-mail: hysarikaya@ttmail.com

R. Yanardag

Department of Chemistry, Faculty of Engineering, Istanbul University, 34320 Istanbul, Turkey

e-mail: refiyeyanardag@yahoo.com 
In recent years, barbiturate and thiobarbiturate derivatives very much attracted considerable attention owing to their various biological effects such as inhibiting collagenase-3 [8] matrix metalloproteinases [9], recombinant cytochrome $\mathrm{P}_{450}$ enzymes [10], methionine aminopeptidase-1 [11], tyrosinase [12], and urease [13]. Also, antioxidant activity values of some arylidene barbiturates have been studied [14].

Arylidene barbiturates are important members of the pyrimidine family. The major importance of these compounds has been centered on their application as useful precursors in the preparation of new heterocyclic bioactive molecules [15] and as potential selective oxidizing agents [16] and for the unsymmetrical synthesis of disulphide [17]. Some of them have been studied as nonlinear optical materials [18]. Due to their importance in the abovementioned, very different methods for barbituric acid synthesis were reported in the literature. Arylidene barbiturates may be synthesized by Knovenagel condensation reaction of barbituric/thioubarbituric acid with various aldehydes [19-21]. The isolated products are mono-substituted as well as di-substituted [22]. To achieve the formation of only one monosubstituted condensation product, various catalysts has been investigated [1, 21, 23].

Free radicals are known to be the major cause of various chronic and degenerative diseases, including aging, coronary heart disease, stroke, inflammation, diabetes mellitus, and cancer $[24,25]$. Reactive oxygen species (ROS) include free radicals such as superoxide anion, hydroxyl radical, singlet oxygen, and hydrogen peroxide can cause cellular injuries and initiate peroxidation of polyunsaturated fatty acids in biological membranes [26]. The tissue injury caused by ROS may include DNA damage, protein damage, and important enzymes in human body [27]. These events could consequently lead to the occurrence of various free-radical-related diseases. Antioxidants are extensively studied for their capacity to protect organisms and cells from damage that is induced by oxidative stress. Nowadays, antioxidants arouse researchers' interest in both medical plants and synthetic compounds. Synthetic antioxidants, such as butylated hydroxyanisole (BHA), butylated hydroxytoluene (BHT), and tert-butylhydroquinone, have been widely used in the food industry to prevent oxidative deterioration, but BHA and BHT are suspected of being responsible for liver damage and carcinogenesis [28]. Scientists in various disciplines have become more interested in new compounds, either synthesized or obtained from natural sources that could provide active components to prevent or reduce the impact of oxidative stress on cells.

Urease (urea amidohydrolase; EC 3.5.1.5) is a nickel-containing metalloenzyme that catalyzes the hydolysis of urea to form ammonia and carbamate [29]. The resulting carbamate spontaneously decomposes to yield a second molecule of ammonia and carbon dioxide. It is present in a variety of plants, algae, fungi, and bacteria in soil enzymes [30]. High concentrations of ammonia arising from these reactions, as well as the accompanying $\mathrm{pH}$ elevation, have important negative implications in medicine and agriculture [31, 32]. Urease is involved in the pathogenesis of hepatic encephalopathy, hepatic coma urolithiasis, pyelonephritis, ammonia, and urinary catheter encrustation [33]. It is also a major cause of pathologies induced by Helicobacter pylori as this allows bacteria to survive at the low $\mathrm{pH}$ of the stomach and hence plays an important role in producing peptic and gastric ulcers [34]. In the near past, a number of compounds have been proposed as urease inhibitors to reduce environmental problems and enhance the uptake of urea nitrogen by plants [35, 36]. Many urease inhibitors have been investigated in the past decades, such as phosphorodiamidates, hydroxamic acid derivatives, and imidazoles, but most of these compounds are too toxic or unstable to allow their use in vivo. Thus, the search is still on for novel urease inhibitors with promising levels of activity [37].

In this study, we have investigated antioxidant, antimicrobial, and urease inhibition activities of some arylidene barbituric acids $(1 \mathrm{a}-\mathrm{g})$ derivatives. Urease inhibitors with antioxidant and antimicrobial properties may be proved as hallmark for the development 
of new antiulcer drugs which will not only clear the $H$. pylori infection but also the induced oxidative stress be redressed.

\section{Materials and Methods}

General

All chemicals and solvents are commercially available and were used after distillation or treatment with drying agents. Antioxidant activities of samples were determined in a spectrophotometer (UV-1240, Shimadzu, Japan).

Studied compounds 1a [38], 1b [11], 1c [39], 1d [11], 1e [40], 1f [41], and 1g [42] were prepared by using literature procedures (Scheme 1; Table 1).

\section{Microbial Strains}

The synthesized compounds were tested individually against 13 gram-positive and gramnegative bacteria species. The bacterial strains used in this study were obtained from the American Type Culture Collection (ATCC) and were as follows: Enterobacter cloaceae ATCC 13047, Enterococcus faecalis ATCC 29212, Salmonella typhimirium ATCC 14028, Staphylococcus epidermidis ATCC 12228, Proteus vulgaris ATCC 13315, Yersinia pseudotuberculosis ATCC 911, Staphylococcus aureus ATCC 25923, Pseudomanas aeruginosa ATCC 27853, Klebsiella pneumoniae ATCC 13883, Bacillus subtilis ATCC6633, Escherichia coli ATCC 35218, Listeria monocytogenes ATCC 7644, and E. faecalis ATCC 51299. All synthesized compounds were weighed and dissolved in dimethyl sulfoxide (DMSO) to prepare extract stock solutions.

\section{Antibacterial Activity with the Agar Well Diffusion Method}

Antibacterial activity was screened by agar well diffusion method [43, 44]. Test bacteria was cultivated overnight in Mueller Hinton Broth medium at $37^{\circ} \mathrm{C}$. Then, Mueller Hinton Agar plates were swabbed (sterile cotton swabs) with $100 \mu \mathrm{L}$ of test bacteria culture which has concentration $\mathrm{OD}_{625}=0.08-0.1$ (approximately $1 \times 10^{7}-1 \times 10^{8} \mathrm{CFU} / \mathrm{mL}$ ). Using the sterile cork borer, the well $(6 \mathrm{~mm})$ was made into the each plate. The test substances were prepared in DMSO which showed no zone of inhibition and acts as a negative control. The

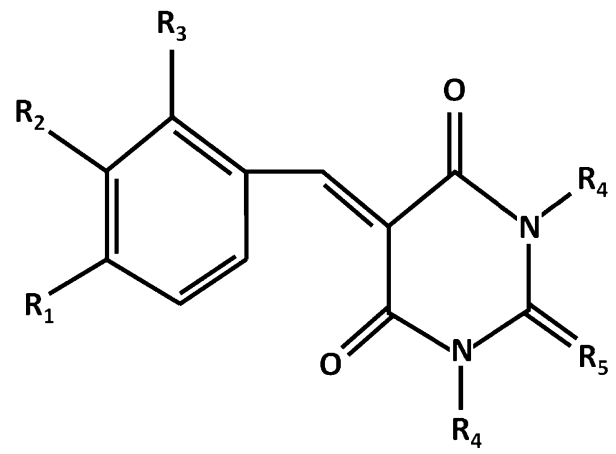

Scheme 1 Studied compounds 
Table 1 Some arylidene barbiturate derivatives used in this study $(1 \mathrm{a}-\mathrm{g})$

\begin{tabular}{llllll}
\hline Compounds & $\mathrm{R}_{1}$ & $\mathrm{R}_{2}$ & $\mathrm{R}_{3}$ & $\mathrm{R}_{4}$ & $\mathrm{R}_{5}$ \\
\hline $1 \mathrm{a}$ & $\mathrm{H}$ & $\mathrm{H}$ & $\mathrm{OH}$ & $\mathrm{H}$ & $\mathrm{O}$ \\
$1 \mathrm{~b}$ & $\mathrm{OH}$ & $\mathrm{H}$ & $\mathrm{H}$ & $\mathrm{H}$ & $\mathrm{O}$ \\
$1 \mathrm{c}$ & $\mathrm{H}$ & $\mathrm{H}$ & $\mathrm{OH}$ & $\mathrm{H}$ & $\mathrm{S}$ \\
$1 \mathrm{~d}$ & $\mathrm{OH}$ & $\mathrm{H}$ & $\mathrm{H}$ & $\mathrm{H}$ & $\mathrm{S}$ \\
$1 \mathrm{e}$ & $\mathrm{H}$ & $\mathrm{H}$ & $\mathrm{OH}$ & $\mathrm{CH}_{3}$ & $\mathrm{O}$ \\
$1 \mathrm{f}$ & $\mathrm{OH}$ & $\mathrm{H}$ & $\mathrm{OH}$ & $\mathrm{CH}_{3}$ & $\mathrm{O}$ \\
$1 \mathrm{~g}$ & $\mathrm{H}$ & $\mathrm{OH}$ & $\mathrm{H}$ & $\mathrm{CH}_{3}$ & $\mathrm{O}$ \\
\hline
\end{tabular}

concentrations of the test substances were prepared as $30 \mathrm{mg} / \mathrm{mL}$. Fifty microliters of the test substances was added into the wells. Simultaneously, an antibiotic, ampicillin (60 mg/mL), was used as positive control and were tested against the microorganisms. Twenty-five microliters of the antibiotic was added into the wells. Then the plates were incubated at $37^{\circ} \mathrm{C}$ for $16-24 \mathrm{~h}$. After the incubation period, the diameter of the inhibition zones of each well was measured. Each experiment was performed in triplicate.

Antioxidant and Urease Enzyme Inhibition Activity

Cuprac-reducing antioxidant capacity of the some arylidene derivatives was determined according to the method described by Apak et al. [45]. Urease inhibitory activity was determined according to Van Slyke and Archilbald [46].

\section{Result and Discussion}

The anti-microbial activity of compounds $1 \mathrm{a}-\mathrm{g}$ and ampicillin was assayed against the grampositive (G+) (E. faecalis ATCC 29212, S. epidermidis ATCC 12228, S. aureus ATCC 25923, B. subtilis ATCC6633, L. monocytogenes ATCC 7644, and E. faecalis ATCC 51299) and gramnegative (G-) (E. cloaceae ATCC 13047, S. typhimirium ATCC 14028, P. vulgaris ATCC 13315, Y. pseudotuberculosis ATCC 911, P. aeruginosa ATCC 27853, K. pneumoniae ATCC 13883, and E. coli ATCC 35218) microorganisms. Anti-microbial activity of the studied bacteria was qualitatively and quantitatively assessed by evaluating the presence of inhibition zones and minimal inhibition concentration (MIC) values [47-50].

Four compounds (1a, 1e, 1f, 1g) showed anti-microbial activity against G+ and G- bacteria tested, and the results are given in Tables 2 and 3. Four compounds (1a, 1e, 1f, 1g) were found to be same active as ampicillin against almost all tested strains. The maximum inhibition zones and MIC values for the bacterial strains that were sensitive to the studied arylidene barbiturates compounds (1a-g) were in the range of $10-27 \mathrm{~mm}$ and from 10.30 to $650 \mu \mathrm{g} / \mathrm{mL}$, respectively (Table 3).

The results indicate that it is clear that the hydroxyl group of the aryl chain influenced the broadening of the spectrum of anti-microbial activity and MIC values of the investigated compounds. Decreasing of the activity was observed in the case of $\mathrm{p}-\mathrm{OH}$ group in aryl chain and due to replacing $\mathrm{O}$ with $\mathrm{S}$ on barbiturate rings. Thioanalogues of arylidene barbiturates have no antibacterial activity as compared with other studied barbiturates. On the other hand, when a hydroxy group was present at o-position in ring-aryl, the activity increased accordingly in arylidene barbiturates. Thus, increase in activity is probably due to the resonance effect of $-\mathrm{OH}$ 
Table 2 Antimicrobial screening data for the studied compounds (1a-g)

\begin{tabular}{|c|c|c|c|c|c|c|c|c|c|}
\hline & \multicolumn{9}{|c|}{ Zone of inhibition (mm) } \\
\hline & $1 \mathrm{a}$ & $1 \mathrm{~b}$ & $1 \mathrm{c}$ & $1 d$ & $1 \mathrm{e}$ & if & $1 \mathrm{~g}$ & AMP & DMSO \\
\hline E. cloaceae ATCC 13047 & 12 & - & - & - & 13 & 14 & - & - & - \\
\hline E. faecalis ATCC 29212 & 19 & - & - & - & 12 & 12 & 17 & 26 & - \\
\hline S. typhimirium ATCC 14028 & 13 & - & - & - & - & 16 & - & 19 & - \\
\hline S. epidermidis ATCC 12228 & 25 & - & - & - & 18 & 20 & 16 & a & - \\
\hline P. vulgaris ATCC 13315 & 26 & - & - & - & - & 20 & - & 25 & - \\
\hline Y. pseudotuberculosis ATCC 911 & - & - & - & - & 18 & 17 & 15 & a & - \\
\hline S. aureus ATCC 25923 & 25 & - & - & - & 20 & 13 & 23 & 35 & - \\
\hline P. aeruginosa ATCC 27853 & - & - & - & - & - & - & - & 32 & - \\
\hline K. pneumoniae ATCC 13883 & - & - & - & - & - & 19 & - & - & - \\
\hline B. subtilis ATCC 6633 & 14 & - & - & - & 15 & 16 & 15 & 31 & - \\
\hline E. coli ATCC 35218 & 11 & - & - & - & - & 19 & - & 15 & - \\
\hline L. monocytogenes ATCC 7644 & 27 & - & - & - & 15 & 17 & 19 & 27 & - \\
\hline E. faecalis ATCC 51299 & 20 & - & - & - & 11 & 10 & 15 & 28 & - \\
\hline
\end{tabular}

$A M P$ ampicillin $(60 \mathrm{mg} / \mathrm{mL})$ as positive control, DMSO negative control

${ }^{\text {a }}$ Not determined

group that is more prominent at o-position than m-position and p-position. Above results show that electron-donating groups like hydroxyl in o-position on the arylchain and oxygen in carbonyl group on the barbiturate rings are responsible for the antibacterial activity of arylidene barbiturates.

The reducing power has been used as one of the antioxidant capability indicators. There was a correlation found between the reducing capabilities and substituents. The reason for the higher

Table 3 Minimum inhibition concentration values of the studied compounds (1a-g)

\begin{tabular}{|c|c|c|c|c|c|c|c|}
\hline & \multicolumn{7}{|c|}{ MIC values $(\mu \mathrm{g} / \mathrm{mL})$} \\
\hline & $1 \mathrm{a}$ & $1 b$ & $1 \mathrm{c}$ & $1 d$ & $1 \mathrm{e}$ & $1 f$ & $1 \mathrm{~g}$ \\
\hline E. cloaceae ATCC 13047 & 325.00 & - & - & - & 325.00 & 81.25 & - \\
\hline E. faecalis ATCC 29212 & 162.50 & - & - & - & 81.25 & 20.60 & 81.25 \\
\hline S. typhimirium ATCC 14028 & 650.00 & - & - & - & - & 81.25 & - \\
\hline S. epidermidis ATCC 12228 & 40.12 & - & - & - & 81.25 & 40.12 & 81.25 \\
\hline P. vulgaris ATCC 13315 & 81.25 & - & - & - & - & 81.25 & - \\
\hline Y. pseudotuberculosis ATCC 911 & - & - & - & - & 325.00 & 162.50 & 650.00 \\
\hline S. aureus ATCC 25923 & 162.50 & - & - & - & 162.50 & 162.50 & 162.50 \\
\hline P. aeruginosa ATCC 27853 & - & - & - & - & - & - & - \\
\hline K. pneumoniae ATCC 13883 & - & - & - & - & - & 40.12 & - \\
\hline B. subtilis ATCC 6633 & 81.25 & - & - & - & 81.25 & 20.60 & 162.50 \\
\hline E. coli ATCC 35218 & 325.00 & - & - & - & 325.00 & 81.25 & 325.00 \\
\hline L. monocytogenes ATCC 7644 & 325.00 & - & - & - & 162.50 & 81.25 & 81.25 \\
\hline E. faecalis ATCC 51299 & 10.30 & - & - & - & 81.25 & 81.25 & 10.30 \\
\hline
\end{tabular}


reducing power capacity of the compounds can be explained by looking into the structure of compounds. In our study, the barbiturates derivatives showed marked cupric ion $\left(\mathrm{Cu}^{+2}\right)$ reducing ability. Cupric ion $\left(\mathrm{Cu}^{+2}\right)$-reducing ability of barbiturate derivatives is shown in Table 4. Cupric ion $\left(\mathrm{Cu}^{+2}\right)$-reducing capability of barbiturates derivatives by cuprac method was found to be concentration-dependent $(25-100 \mu \mathrm{g} / \mathrm{mL})$. Compounds $1 \mathrm{~b}$ and $1 \mathrm{f}$ showed the lowest cupric ion $\left(\mathrm{Cu}^{+2}\right)$-reducing capability (Table 3 ). Compounds $1 \mathrm{~g}, 1 \mathrm{e}$, and 1a exhibited the moderate effect on reducing power. The highest reducing capacity was found for $1 \mathrm{c}$ and $1 \mathrm{~d}$ barbiturate derivatives. Thioanalogues of arylidene barbiturates have antioxidant activity as compared with other studied barbiturates. Cupric ion $\left(\mathrm{Cu}^{+2}\right)$-reducing power of barbiturates

Table 4 Cupric ions reducing antioxidant capacity of different concentration of barbiturate derivatives

\begin{tabular}{|c|c|c|}
\hline Compounds & $\begin{array}{l}\text { Barbiturate derivatives } \\
\text { concentration }(\mu \mathrm{g} / \mathrm{mL})\end{array}$ & Absorbance $^{\mathrm{a}}$ \\
\hline \multirow[t]{4}{*}{ 1a } & 25 & $0.253 \pm 0.012$ \\
\hline & 50 & $0.296 \pm 0.017$ \\
\hline & 75 & $0.372 \pm 0.015$ \\
\hline & 100 & $0.408 \pm 0.014$ \\
\hline \multirow[t]{4}{*}{$1 b$} & 25 & $0.206 \pm 0.009$ \\
\hline & 50 & $0.252 \pm 0.014$ \\
\hline & 75 & $0.308 \pm 0.003$ \\
\hline & 100 & $0.342 \pm 0.005$ \\
\hline \multirow[t]{4}{*}{$1 \mathrm{c}$} & 25 & $0.116 \pm 0.003$ \\
\hline & 50 & $1.242 \pm 0.012$ \\
\hline & 75 & $1.330 \pm 0.006$ \\
\hline & 100 & $1.429 \pm 0.044$ \\
\hline \multirow[t]{4}{*}{$1 d$} & 25 & $1.035 \pm 0.006$ \\
\hline & 50 & $1.196 \pm 0.018$ \\
\hline & 75 & $1.344 \pm 0.041$ \\
\hline & 100 & $1.372 \pm 0.020$ \\
\hline \multirow[t]{4}{*}{ 1e } & 25 & $0.225 \pm 0.007$ \\
\hline & 50 & $0.294 \pm 0.008$ \\
\hline & 75 & $0.348 \pm 0.005$ \\
\hline & 100 & $0.508 \pm 0.006$ \\
\hline \multirow[t]{4}{*}{ 1f } & 25 & $0.197 \pm 0.022$ \\
\hline & 50 & $0.260 \pm 0.004$ \\
\hline & 75 & $0.279 \pm 0.011$ \\
\hline & 100 & $0.358 \pm 0.006$ \\
\hline \multirow[t]{4}{*}{$1 \mathrm{~g}$} & 25 & $0.293 \pm 0.008$ \\
\hline & 50 & $0.355 \pm 0.004$ \\
\hline & 75 & $0.420 \pm 0.013$ \\
\hline & 100 & $0.647 \pm 0.008$ \\
\hline \multirow[t]{4}{*}{ BHT } & 25 & $0.586 \pm 0.016$ \\
\hline & 50 & $0.997 \pm 0.022$ \\
\hline & 75 & $1.394 \pm 0.016$ \\
\hline & 100 & $1.575 \pm 0.009$ \\
\hline
\end{tabular}

${ }^{\mathrm{a}} \mathrm{Mean} \pm \mathrm{SD}$ 
derivatives and BHT at the same concentration $(100 \mu \mathrm{g} / \mathrm{mL})$ exhibited the following order: BHT $>1 \mathrm{c}>1 \mathrm{~d}>1 \mathrm{~g}>1 \mathrm{e}>1 \mathrm{a}>1 \mathrm{f}>1 \mathrm{~b}$.

Certain synthetic compounds have shown potential urease inhibition such as hydroxyurea, flurofamide, and hydroxyamic acid; however, the in vivo use of some of these has been prohibited because of their toxicity or instability; for instance, acetohydroxyamic acid has been demonstrated to be teratogenic in rats [51]. The discovery of potent and safe urease

Table 5 The urease inhibitory activity of different concentrations of barbiturates derivatives.

\begin{tabular}{|c|c|c|c|c|}
\hline $\begin{array}{l}\text { Table } 5 \text { The urease inhibitory } \\
\text { activity of different concentrations } \\
\text { of barbiturates derivatives. }\end{array}$ & Compounds & $\begin{array}{l}\text { Barbiturate derivatives } \\
\text { concentration }(\mu \mathrm{g} / \mathrm{mL})\end{array}$ & $\begin{array}{l}\text { Inhibition } \\
(\%)^{\mathrm{a}}\end{array}$ & $\mathrm{IC}_{50}(\mu \mathrm{M})^{\mathrm{a}}$ \\
\hline & 1a & 0.001 & $17.83 \pm 1.55$ & $2.582 \pm 0.114$ \\
\hline & & 0.01 & $27.67 \pm 2.21$ & \\
\hline & & 0.1 & $45.66 \pm 6.00$ & \\
\hline & & 1 & $63.07 \pm 0.96$ & \\
\hline & $1 \mathrm{~b}$ & 0.001 & $21.90 \pm 1.59$ & $1.841 \pm 0.081$ \\
\hline & & 0.01 & $32.93 \pm 2.50$ & \\
\hline & & 0.1 & $49.36 \pm 3.17$ & \\
\hline & & 1 & $72.06 \pm 2.02$ & \\
\hline & $1 \mathrm{c}$ & 0.001 & $25.36 \pm 2.58$ & $0.054 \pm 0.006$ \\
\hline & & 0.01 & $37.61 \pm 4.21$ & \\
\hline & & 0.1 & $61.16 \pm 3.52$ & \\
\hline & & 1 & $73.03 \pm 1.08$ & \\
\hline & $1 \mathrm{~d}$ & 0.001 & $23.61 \pm 3.10$ & $0.038 \pm 0.003$ \\
\hline & & 0.01 & $53.44 \pm 4.33$ & \\
\hline & & 0.1 & $62.55 \pm 2.50$ & \\
\hline & & 1 & $75.77 \pm 1.57$ & \\
\hline & $1 \mathrm{e}$ & 0.001 & $31.40 \pm 2.46$ & $0.036 \pm 0.002$ \\
\hline & & 0.01 & $57.86 \pm 3.56$ & \\
\hline & & 0.1 & $67.98 \pm 3.94$ & \\
\hline & & 1 & $77.09 \pm 2.52$ & \\
\hline & $1 \mathrm{f}$ & 0.001 & $22.88 \pm 1.10$ & $0.050 \pm 0.004$ \\
\hline & & 0.01 & $38.29 \pm 2.75$ & \\
\hline & & 0.1 & $52.17 \pm 4.10$ & \\
\hline & & 1 & $73.84 \pm 0.83$ & \\
\hline & $1 \mathrm{~g}$ & 0.001 & $37.61 \pm 3.40$ & $0.033 \pm 0.151$ \\
\hline & & 0.01 & $51.86 \pm 1.30$ & \\
\hline & & 0.1 & $63.85 \pm 2.09$ & \\
\hline & & 1 & $76.03 \pm 2.33$ & \\
\hline & Thiourea & 0.001 & $34.92 \pm 0.85$ & $8.825 \pm 1.601$ \\
\hline & & 0.01 & $38.72 \pm 1.75$ & \\
\hline & & 0.1 & $43.12 \pm 1.48$ & \\
\hline & & 1 & $45.36 \pm 1.04$ & \\
\hline & Hydroxyurea & 0.001 & $29.76 \pm 2.36$ & $7.418 \pm 0.012$ \\
\hline & & 0.01 & $33.24 \pm 0.95$ & \\
\hline & & 0.1 & $36.95 \pm 2.13$ & \\
\hline & & 1 & $38.61 \pm 1.43$ & \\
\hline
\end{tabular}

${ }^{\mathrm{a}} \mathrm{Mean} \pm \mathrm{SD}$ 
inhibitors has been a very important area of pharmaceutical research due to the involvement of urease in different pathological conditions.

Urease inhibitor activity of was given in Table 5 . Table 5 shows that the arylidene barbiturate derivatives are more potent than the standard inhibitor of urease, hydroxyurea, and thiourea. Thiourea and hydroxyurea are the main examples of the substrate-like urease inhibitors. The inhibition was increased with increasing barbiturate concentration. $\mathrm{IC}_{50}$ values for barbiturate compounds were found to be $0.033-2.582 \mu \mathrm{M}$. Compounds $1 \mathrm{~g}$ and $1 \mathrm{e}$ proved to be the most potent showing an enzyme inhibition activity with an $\mathrm{IC}_{50}=0.033-0.036 \mu \mathrm{M}$. The least active compound $1 \mathrm{a}$ had an $\mathrm{IC}_{50}=2.582 \mu \mathrm{M}$. All of the compounds showed high potent activity than that of standard hydroxyurea $\left(\mathrm{IC}_{50}=7.418 \mu \mathrm{M}\right)$ and thiourea $\left(\mathrm{IC}_{50}=8.825 \mu \mathrm{M}\right)$. In the other study, synthesized polyphenol compounds $\left(\mathrm{IC}_{50}=22-43.8 \mu \mathrm{M}\right)$ had a lower urease inhibitor activity than in our study. The discovery that barbituric acid inhibits urease was made by Gray et al., who observed that certain cyclic urea compounds (i.e., barbituric and thiobarbituric acids) were capable of inhibiting bacterial and jack-bean urease [52, 53]. Tanaka et al. demonstrated that some alpha hydroxyketone derivatives show urease inhibitory activity [54]. Xiao et al. reported some synthesized pyrogallol and catechol derivatives as H. pylori urease inhibitors [55]. Many synthetic and natural apple polyphenols have shown inhibitory activity against urease activity [56]. Rauf et al. reported that some barbituric acid- and thiobarbituric acidderived sulfonamides were urease inhibitors [57]. In our study, the synthesized compounds can be regarded as substrate-like inhibitors based on their structural similarity to the natural substrate of urease, urea, and thiourea. Since all the synthesized barbiturate compounds promise urease inhibitor activity, this may be due to their basic skeleton.

The presence of $-\mathrm{S}$ and $-\mathrm{O}$ of barbiturate derivatives isomers in this study may together play a great role on urease inhibition activity.

\section{Conclusions}

In our study, some arylidene barbiturates have been synthesized, and their antibacterial, antiurease, and antioxidant activities were evaluated. The results showed that all of arylidene barbiturate derivatives exhibited antiurease and antioxidant activities. According to our results, there is a correlation between antiurease, antibacterial, and antioxidant activities of compounds and substituents. Among the synthesized compounds, compounds $1 \mathrm{c}$ and $1 \mathrm{~d}$ were found to be the most active reducing agent. Compounds $1 \mathrm{~g}, 1 \mathrm{e}, 1 \mathrm{~d}$, and $1 \mathrm{f}$ were determined to be have the highest antiurease activity. Also, compounds 1a, 1e, 1f, and $1 \mathrm{~g}$ were showed to be the highest antibacterial activity. These arylidene barbiturates can be used in agriculture and pharmacy industries due to their excellent antibacterial, antiurease, and antioxidant activities.

Conflict of interest The authors declare no financial or other relationship that might lead to a conflict of interest.

Open Access This article is distributed under the terms of the Creative Commons Attribution License which permits any use, distribution, and reproduction in any medium, provided the original author(s) and the source are credited.

\section{References}

1. Khan, K. M., Ali, M., Farooqui, T. A., Khan, M., Taha, M., \& Perveen, S. (2009). Journal of the Chemical Society of Pakistan, 31, 823-828. 
2. Levina, R. Y., \& Velichko, F. K. (1960). Russian Chemical Reviews, 29, 437-438.

3. Sing, P., \& Paul, K. (2006). Indian Journal of Chemistry, 45B, 247-251.

4. Cheng, X., Tanaka, K., \& Yoneda, F. (1990). Chemical and Pharmaceutical Bulletin, 38, 307-311.

5. Morgan, L. R., Jursic, B. S., Hooper, C. L., Neumann, D. M., Thangaraj, K., \& LeBlanc, B. (2002). Bioorganic \& Medicinal Chemistry Letters, 12, 3407-4011.

6. Orzalesi, G. P., Gratteri, P., \& Selleri, S. (1990). European Journal of Medicinal Chemistry, 25, $197-201$.

7. Puerta, D. T., \& Cohen, S. M. (2004). Current Topics in Medicinal Chemistry, 4, 1551-1573.

8. Kim, S. H., Pudzianowski, A. T., Leavitt, K. J., Barbosa, J., McDonnell, P. A., Metzler, W. J., Rankin, B. M., Liu, R., Vaccaro, W., \& Pitts, W. (2005). Bioorganic \& Medicinal Chemistry Letters, 15, 1101-1106.

9. Daniewski, A. R., Liu, W., \& Okabe, M. (2004). Organic Proceedings Research and Development, 8, 411-414.

10. Suzuki, H., Kneller, M. B., Rock, D. A., Jones, J. P., Trager, W. F., \& Rettie, A. E. (2004). Archives of Biochemistry and Biophysics, 429, 1-15.

11. Haldar, M. K., Scott, M. D., Sule, N., Srivastava, D. K., \& Mallik, S. (2008). Bioorganic \& Medicinal Chemistry Letters, 18, 2373-2376.

12. Yan, Q., Cao, R., Yi, W., Chen, Z., Wen, H., Ma, L., \& Song, H. (2009). European Journal of Medicinal Chemistry, 44, 4235-4243.

13. Khan, K. M., Ali, M., Wadood, A., Haq, Z., Khan, M., Lodhia, M. A., Perveen, S., Coudhary, M. I., \& Voelter, W. (2011). Journal of Molecular Graphics \& Modelling, 30, 153-156.

14. Khan, K. M., Ali, M., Ajaz, A., Perveen, S., Choudhary, M. I., \& Rahman, A. U. (2008). Letters Drugs Design Discovery, 5, 286-291.

15. Tietze, L. F., \& Bartels, C. (1991). Liebigs Annals Chemistry, 2, 155-160.

16. Tanaka, K., Cheng, X., Kimura, T., \& Yoneda, F. (1986). Chemical and Pharmaceutical Bulletin, 34, 3945-3948.

17. Tanaka, K., Cheng, X., \& Yoneda, F. (1988). Tetrahedron, 44, 3241-3249.

18. Ikeda, H., Kawabe, Y., Sakai, T., \& Kawasaki, K. (1989). Chemistry Letters, 10, 1803-1809.

19. Ashnagar, A., Naseri, N. G., \& Sheeri, B. (2007). Chinese Journal of Chemistry, 25, 382-384.

20. D’yachkov, A. I., Ivin, B. A., Smorygo, N. A., \& Sochilin, E. G. (1976). Zhurnal Bioorganicheskaia Khimiia, 12, 1115-1122.

21. Reddy, C. S., \& Nagaraj, A. (2007). Chinese Chemical Letters, 18, 1431-1435.

22. Baeyer, A. (1864). Liebigs Annals Chemistry, 130, 129-175.

23. Alcerreca, G., Sanabria, R., Miranda, R., Arroyo, G., Tamariz, J., \& Delgado, F. (2000). Synthetic Communications, 30, 1295-1301.

24. Heo, S. J., Park, E. J., Lee, K. W., \& Jeon, Y. J. (2005). Bioresource Technology, 96, 1613-1623.

25. Cheng, H. Y., Lin, T. C., Yu, K. H., Yang, C. M., \& Lin, C. C. (2003). Biological and Pharmaceutical Bulletin, 26, 1331-1335.

26. Halliwell, B. (1997). Nutrition Reviews, 55, S44-S49.

27. Wua, S. J., \& Ng, L. T. (2008). LWT-Food Science and Technology, 41, 323-330.

28. Grice, H. P. (1988). Food and Chemical Toxicology, 26, 717-723.

29. Sumner, J. B. (1926). Journal of Biological Chemistry, 69, 435-441.

30. Krajewska, B. (2002). Wiadomosci Chemiczne, 56, 223-253.

31. Zonia, L. E., Stebbins, N. E., \& Polacco, J. C. (1995). Plant Physiology, 107, 1097-1103.

32. Montecucco, C. R., \& Rappuoli, R. (2001). Nature Reviews. Molecular Cell Biology, 2, 457-466.

33. Mobley, H. L. T., Island, M. D., \& Hausinger, R. P. (1995). Microbiological Reviews, 59, 451-480.

34. Mobley, H. L. T., \& Hausinger, P. (1989). Microbiological Reviews, 53, 85-108.

35. McCarty, G. W., Bremner, J. M., \& Lee, J. S. (1990). Plant and Soil, 127, 269-283.

36. Khan, K. M., Wadood, A., Ali, M., Ullah, Z., Ul-Haq, Z., Lodhi, M. A., Khan, M., Perveen, S., \& Choudhary, M. I. (2010). Journal of Molecular Graphics \& Modelling, 28, 792-798.

37. Amtul, Z., Rahman, A. U., Siddiqui, R. A., \& Choudhary, M. I. (2002). Current Medicinal Chemistry, 9, 1323-1348.

38. Goudgaon, N. M., Patil, S. B., Rahaman, S. A., \& Reddy, C. H. (2010). Journal of the Indian Chemical Society, $87,743-748$.

39. Luo, Y., Ma, L., Zheng, H., Chen, L., Rui, L., He, C., Yang, S., Ye, X., Chen, Z., Li, Z., Gao, Y., Han, J., He, G., Yang, L., \& Wei, Y. (2010). Journal of Medicinal Chemistry, 53, 273-281.

40. Naya, S., Miyagawa, M., \& Nitta, M. (2005). Tetrahedron, 61, 4919-4930.

41. Khan, K. M., Khan, M., Ali, M., Taha, M., Hameed, A., Ali, S., Perveen, S., \& Coudhary, I. M. (2011). Medicinal Chemistry, 7, 231-236.

42. Bednar, R., Polansky, O. E., \& Wolschann, P. (1975). Zeitschrift fur Naturforschung, 30b, 582-586.

43. Chung, K. T., Thomasson, W. R., \& Wu-Yuan, C. D. (1990). Journal of Applied Bacteriology, 69, 498503.

44. Azoro, C. (2002). World Journal of Biotechnology, 3, 347-357. 
45. Apak, R., Guclu, K., Ozyurek, M., Karademir, S. E., \& Ercag, E. (2006). International Journal of Food Sciences and Nutrition, 57, 292-304.

46. Van Slyke, D. D., \& Archibald, R. M. (1944). Journal of Biological Chemistry, 154, 623-642.

47. Ozer, H. H., Sokmen, M., Gulluce, M., Adıguzel, A., Sahin, F., Sokmen, A., Kılıc, H., \& Barıs, O. (2007). Journal of Agricultural and Food Chemistry, 55, 937-942.

48. Amelia, A. A., Farah, A., Silva, D. A., Nunan, E. A., \& Gloria, M. B. (2006). Journal of Agricultural and Food Chemistry, 54, 8738-8743.

49. Demirbag, Z., Belduz, A. O., Sezen, K., \& Nalcacioglu, R. (1997). KÜKEM Dergisi, 20, 47-53.

50. Willanova, P.A. (1993) NCCLS document M7-A313 (25), National Committee for Clinical Laboratory Standard, USA.

51. Xiao, Z. P., Shi, D. H., Li, H. Q., Zhang, L. N., Xu, C., \& ZHu, H. L. (2007). Bioorganic \& Medicinal Chemistry, 15, 3703-3710.

52. Gray, C. T., Brooke, M. S., \& Gerhart, J. C. (1959). Nature, 184, 1936-1937.

53. Gray, C. T., Brooke, M. S., \& Gerhart, J. C. (1961). Journal of Bacteriology, 81, 755-761.

54. Tanaka, T., Kawase, M., \& Tani, S. (2004). Bioorganic \& Medicinal Chemistry, 12, 501-505.

55. Xiao, Z. P., Ma, T. W., Fu, W. C., Peng, X. C., Zhang, A. H., \& Zhu, H. L. (2010). European Journal of Medicinal Chemistry, 45, 5064-5070.

56. Pastene, E., Troncoso, M., Figueroa, G., Alarcon, J., \& Speisky, H. (2009). Journal of Agricultural and Food Chemistry, 57, 416-424.

57. Rauf, A., Ahmed, F., Qureshu, A. M., Aziz-ur-ehman, A. K., Qadır, M. I., Choudhary, M. I., Chohan, Z. H., Youssoufid, M. H., \& Hadda, T. B. (2011). Journal of the Chinese Chemical Society, 58, 528-537. 